\title{
Morpho-Physiological and Genetic Responses of Bali Local Rice Cultivars to Drought Stress at Seedling Stage
}

\author{
${ }^{1}$ Made Pharmawati and ${ }^{2}$ Luh Putu Wrasiati \\ ${ }^{1}$ Department of Biology, Faculty of Mathematics and Natural Sciences, \\ ${ }^{2}$ Department of Agroindustrial Technology, Faculty of Agricultural Technology, \\ Udayana University, Kampus Bukit Jimbaran, Badung, Bali 80361, Indonesia
}

Article history

Received: 25-01-2018

Revised: 01-03-2018

Accepted: 27-03-2018

Corresponding Author: Made Pharmawati

Department of Biology, Faculty of Mathematics and Natural Sciences, Udayana University, Kampus Bukit Jimbaran,

Badung, Bali 80361, Indonesia Email: made_pharmawati@unud.ac.id

\begin{abstract}
Rice is the main food source in many countries in the world. One of the major limiting factors for rice growth and productivity is drought stress. In Bali there are several local rice cultivars, two of them are 'Mansur' and 'Putih Cempaka'. The cultivar 'IR 64' is one rice cultivar released by IRRI. The responses of those rice cultivars to drought stress were tested. This study aimed to analyze growth responses and expression of $D R E B$ and SOD genes under drought stress induced by PEG. Rice seedlings were grown in a hydroponic system. Two weeks old seedlings were treated with PEG 20\% $(-0.49 \mathrm{MPa})$ and $30 \%(-1.03 \mathrm{MPa})$ for three days. Root to shoot ratio was calculated and chlorophyll content was measured. RNA was extracted from the shoot. Semi-quantitative real-time PCR was conducted and the products were visualized using 1\% agarose gel electrophoresis. The result showed that root to shoot ratio increased as PEG concentration increased in all rice cultivars tested. The chlorophyll content decrease under PEG treatments in all rice cultivars. The expression of Superoxide Dismutase $(\mathrm{Cu} / \mathrm{Zn}-\mathrm{SOD})$ gene increased under drought treatmentsin 'Mansur' and 'Putih Cempaka', while in 'IR64' using SOD primer tested, the gene was not expressed. The expression of DehydrationResponsive Element Binding (DREB1) gene increased under PEG treatments both in 'Mansur' and 'Putih Cempaka'.
\end{abstract}

Keywords: Gene Expression, Morpho-Physiology, Rice, Drought

\section{Introduction}

Rice (Oryza sativa L.) is a primary source of food for people in many countries including Indonesia. Rice productivity is affected by several factors such as high temperature, salinity and drought stress. Among various abiotic stresses, the main yield producing factor is drought stress (Karim and Rahman, 2015). Drought stress in plant is a condition of inadequate water availability in plant environment. This can be due to lack of water supply in the root areas and the need for excessive water by leaves because of high transpiration rate that exceeding the rate of water absorption (Farooq et al., 2012). Drought leads to the decrease of photosynthesis and disturbance of enzymes activity especially those involved in ATP synthesis (Farooq et al., 2012). Drought stress conditions change the structure of roots such as increased root branch and density (Eghball and Maranville, 1993).
In Indonesia, El Niño/Southern Oscillation (ENSO) event induced early season droughts, delayed onset of the monsoon and delayed planting of rice which in the end leads to rice production shortfall (Naylor et al., 2007). Between 1979-2004, ENSO events caused rice production reduced by $11 \%$ in East Java/Bali during the main rice harvest season between January and April, while in West/Central Java the reduction was $6.5 \%$ (Naylor et al., 2007).

Plants develop a variety of mechanisms to adapt to environmental stresses including reprogramming of gene expression (Romo et al., 2001) such as the decrease of mRNA level related to photosynthesis (Bartels and Nelson, 2004). Certain genes will be induced if plants under drought stress. The product of those genes involved in cellular protection to damage caused by stress. Changes in expression of genes responsive to stress are an important mechanism in plant adaptation. Among several 
genes that are known to be responsive to drought stress, two of them are Dehydration-Responsive Element Binding (DREB) and Superoxide Dismutase (SOD).

Superoxide dismutase genes responsible for antioxidant enzymes that block oxidative stress (Aydin et al., 2014). Drought condition induces the presence of Reactive Oxygen Species (ROS) including superoxide radicals $\left(\mathrm{O}_{2}-\right)$, singlet oxygen $\left(\mathrm{O}_{2}\right)$, hydroxyl radicals $(\mathrm{OH}-)$ and hydrogen peroxide $\left(\mathrm{H}_{2} \mathrm{O}_{2}\right)$ (You and Chan, 2015). Activation of antioxidant enzymes is required to protect plant cell from oxidative damage. DREB regulates protection of plant to abiotic stress. DREB1 is involved in the mechanism of plant tolerance to drought, cold and salinity (Jadhao et al., 2014).

Drought stress can be stimulated by the addition of Polyethylene Glycol (PEG). Polyethylene glycol with high molecular weight is an osmotic regulator that decrease water potential in nutrient without being absorbed by (Roy et al., 2009). The solution of PEG 6000 has been used in many studies of drought stress in plant (Aydin et al., 2014).

Bali local rice 'Mansur' and 'Putih Cempaka' are two among several bali rice cultivars grown in Bali, Indonesia. 'Mansur' is a member of subspecies Indica, while 'Putih Cempaka' is Javanica rice (Budiwati, 2016). Bali local rice has long stem and tassel. The harvesting time is approximately six months. 'IR64' is one of rice superior quality rice cultivar released by Philippine Seed-board in 1985 (Khush and Virk, 2005). This cultivar is widely planted in many countries. 'IR64' has an early maturity, approximately 117 days (Khush and Virk, 2005). This study aimed to evaluate respond of Bali local rice 'Mansur' and 'Putih Cempaka' to drought stress at seedling stage and compare it to 'IR64' including root length, fresh weight root to shoot ratio, chlorophyll content and $D R E B$ and $S O D$ gene expression.

\section{Materials and Methods}

\section{Plant Materials, Planting and Treatments}

Seeds of Bali local rice ('Mansur' and 'Putih Cempaka') and 'IR 64' were collected from a farmer in Tabanan Regency, Bali. The cultivar of 'IR64' was included as a comparison between Bali local rice and the superior rice quality. Seedlings were grown in Rockwool cubes as growing media in seedling trays for one week. After that, seedlings were transferred to static hydroponic system supplemented by $1 / 4$ Murashige and Skoog (MS) nutrient (Pardo et al., 1998). Five seedlings were grown in each pot. The seedlings were grown for another week and PEG 6000 were added at the concentration of $20 \%(-0.49 \mathrm{MPa})$ and $30 \%(-1.03 \mathrm{MPa})$ as severe drought stress for three days, following Lima et al.
(2015) with modification. The experiment was conducted in a factorial design with three replicates.

\section{Measurement of Morpho-Physiological Characters}

At the end of treatment period, seedlings were harvested and root length, fresh weight of shoot and root were measured. The ratio of the fresh weight of root to shoot was calculated. Chlorophyll content was extracted using $80 \%$ acetone and calculated according to Arnon (1949).

\section{Gene Expression}

The analyses of DREB and SOD expression were done using semi-quantitative real-time PCR. The shoot was collected three days after treatments and RNA were extracted using RNeasy Plant Mini Kit (Qiagen) according to manufacturer instruction. RNA concentration was measured using spectrophotometer at $260 \mathrm{~nm}$ and $280 \mathrm{~nm}$ (Sambrook and Russell, 2001). Synthesis of cDNA was done using Transcriptor First Strand cDNA Kit (Roche) following manufacturer protocol. PCR was done using cDNA as template. Amplification of $S O D$ gene was conducted using forward primer GTCCATCGTAGATGAACCGTC and CGATCCATCTGAGATCCACAC as reverse primer (Singh and Sadasivam, 2003). DREB amplification was conducted using forward primer sequence CCGTTGATTGCTGATAGCCTCCTTGA and reverse primer sequence TGAAATATTCCTATTGACCCGCAGCA (Wang et al., 2004). Actin was used as control gene and amplified using primer CTTCCTCATGCCATCCTGC (forward) and GCAAGCTTCTCCTTGATGTCC (reverse) (Yu et al., 2007) in a thermal cycler (Infinigen Biotech, CA, USA). PCR consisted of $1 \mu \mathrm{L}$ cDNA, $1 \times$ PCR buffer (MDBio, USA), $200 \mu \mathrm{M}$ dNTP (Promega, USA), $2.5 \mathrm{mM} \mathrm{MgCl}_{2}$, $0.5 \mu \mathrm{M}$ of each forward and reverse primers, $1 \mathrm{U}$ Taq polymerase (MDBio, USA) and $\mathrm{H}_{2} \mathrm{O}$ to reach $25 \mu \mathrm{L}$ reaction. The cycles of PCR were $1 \times$ denaturation at $95^{\circ} \mathrm{C}$ for $5 \mathrm{~min}$, followed by $35 \times$ denaturation at $95^{\circ} \mathrm{C}$ for $1 \mathrm{~min}$, annealing at $52^{\circ} \mathrm{C}(D R E B), 60^{\circ} \mathrm{C}(S O D)$ and $56^{\circ} \mathrm{C}$ (Actin) for $1 \mathrm{~min}$ and extension at $72^{\circ} \mathrm{C}$ for 1 min. This cycle was followed by one cycle of final extension at $72^{\circ} \mathrm{C}$ for $10 \mathrm{~min}$.

Electrophoresis was done in $1.5 \%$ agarose gel in $1 \times$ TAE buffer (Tris Acetic Acid, EDTA) at 100 volts for $45 \mathrm{~min}$. The gel was stained using ethidium bromide and visualized using GelDoc UV transilluminator (Uvitec, UK). Quantification of gene expression was performed using ImageJ software (NIH; http://rsb. info.nih.gov/ij/).

\section{Statistical Analysis}

The root length, fresh weight root to shoot ratio and chlorophyll content were analyzed using one-way ANOVA and significant between means were analyzed 
using Duncan's test at $5 \%$ probability levels $(\mathrm{p} \leq 0.05)$. Two-way factorial ANOVA was used to determine the interaction between treatment and cultivar.

\section{Results}

\section{Morpho-Physiological Responses to Drought}

There was a reduction in shoot length in the three rice cultivars after PEG treatments, however, the values were not significantly different (data not shown). Statistical analysis showed that there was no interaction between root length and cultivars.

Root length of rice cultivar 'Mansur' increased significantly under PEG treatments (Table 1). There were no changes in root length of 'Putih Cempaka' between control and PEG-treated seedling, while in 'IR64' root length was reduced at higher concentration of PEG (Table 1).

The ratio of root to shoot fresh weight of increased as the concentration of PEG increased (Table 2). The rice cultivars responded differently in root to shoot ratio under drought stress. There was an interaction between treatments and cultivars in root to shoot ratio. The maximum increase of root to shoot ratio $(0.57 \mathrm{~g})$ was observed at rice cultivar 'Putih Cempaka' at 30\% PEG, while the minimum increase was at 'Mansur' with 20\% PEG treatment $(0.049 \mathrm{~g})$.

Table 3 showed chlorophyll content in 'Mansur', 'Putih Cempaka' and 'IR64' under drought stress. Statistical analysis showed that chlorophyll content under drought differed in rice cultivars. Plants treated with PEG have lower chlorophyll content than control plants. Treatment with $30 \%$ PEG resulted in the lowest chlorophyll content in all rice cultivars. The maximum

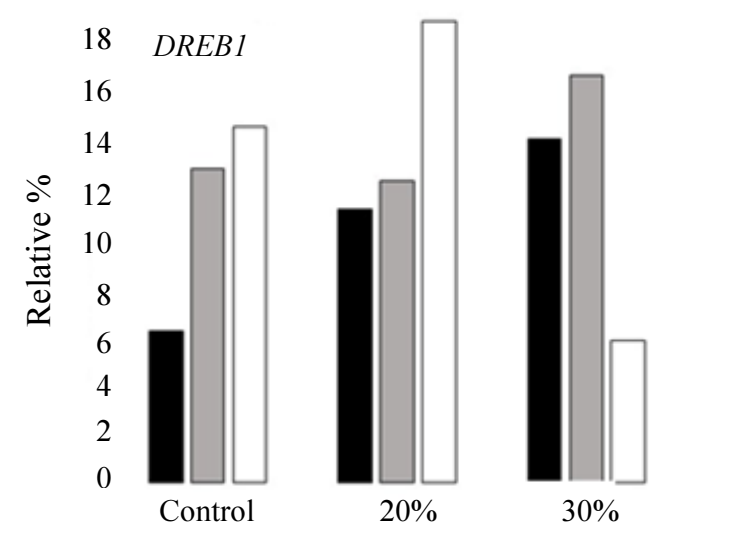

PEG concentration

'Mansur' $\square$ 'Putih Cempaka' $\square$ 'IR64' reduction of chlorophyll content was at 'Putih Cempaka' treated with $30 \%$ PEG $(-7.277 \mathrm{mg} / \mathrm{mL})$. Rice cultivar 'IR64' with PEG treatment showed the minimum reduction of chlorophyll both at 20\% PEG and 30\% PEG i.e., -1.768 and $-2.929 \mathrm{mg} / \mathrm{mL}$ respectively.

\section{Gene Expression under Drought}

The expression of SOD gene increased under PEG stressed in 'Mansur' and 'Putih Cempaka', while in 'IR64', SOD was not expressed both in untreated and PEG-treated seedling (Fig. 1).

Both concentrations of PEG treatments increased expression of DREB gene in 'Mansur' and 'Putih Cempaka'. On the contrary, in 'IR64', the expression of $D R E B$ increased only at $20 \%$ PEG and decreased at $30 \%$ PEG. The histograms in Fig. 2 were the quantification of $S O D$ and $D R E B$ expression using the Image J software.

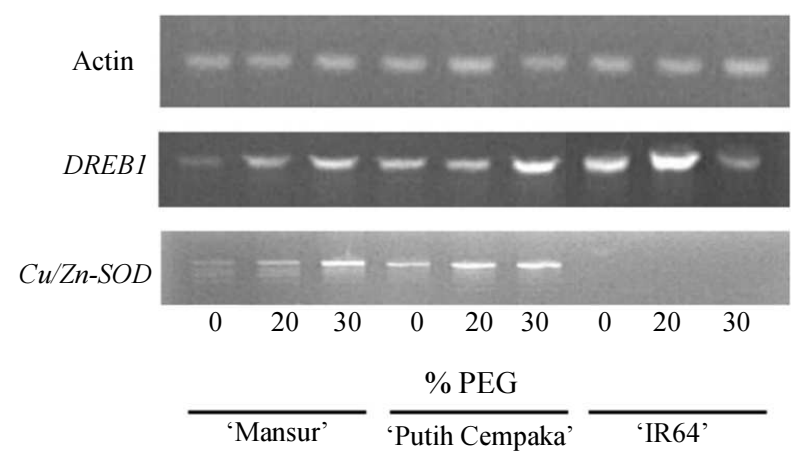

Fig. 1: Expression of $C u / Z n-S O D$ and $D R E B 1$ in Bali local rice cultivars 'Mansur', 'Putih Cempaka' and 'IR64' after PEG treatment. Actin was used as a transcriptional control gene

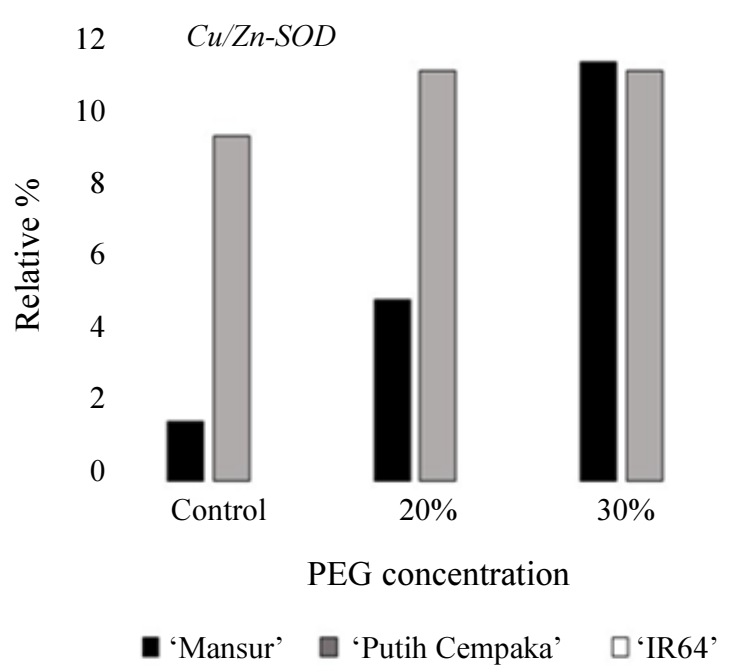

Fig. 2: Quantification of $D R E B 1$ and $C u / Z n-S O D$ and Actin expression calculated using ImageJ software 
Table 1: Root length after three days treatment with PEG Length $(\mathrm{cm})$

\begin{tabular}{|c|c|c|c|}
\hline \multirow[b]{2}{*}{ Treatment } & & & \\
\hline & 'Mansur' & 'Putih Cempaka' & 'IR64' \\
\hline Control & $10.93 \pm 0.176^{\mathrm{a}}$ & $12.43 \pm 0.426^{\mathrm{a}}$ & $8.23 \pm 0.426^{\mathrm{a}}$ \\
\hline PEG $20 \%$ & $12.03 \pm 0.797^{\mathrm{b}}$ & $12.27 \pm 0.267^{\mathrm{a}}$ & $8.50 \pm 0.289^{\mathrm{a}}$ \\
\hline PEG $30 \%$ & $12.50 \pm 0.252^{b}$ & $12.03 \pm 0.77^{\mathrm{a}}$ & $6.83 \pm 0.167^{b}$ \\
\hline
\end{tabular}

Numbers are average from 3 replicates \pm SD. Means with same letters in the same column are not significantly different

Table 2: Fresh weight root to shoot ratio after three days treatment with PEG

\begin{tabular}{|c|c|c|c|c|}
\hline \multirow[b]{2}{*}{ Treatment } & \multicolumn{4}{|c|}{ Root to shoot Ratio (g) } \\
\hline & 'Mansur' & 'Putih Cempaka' & 'IR64' & Average \\
\hline Control & $0.438 \pm 0.017^{\mathrm{a}}$ & $0.407 \pm 0.030^{\mathrm{a}}$ & $0.254 \pm 0.042^{\mathrm{c}}$ & $0.366^{\mathrm{A}}$ \\
\hline PEG $20 \%$ & $0.487 \pm 0.018^{\mathrm{a}}$ & $0.563 \pm 0.058^{\mathrm{ab}}$ & $0.316 \pm 0.020^{c}$ & $0.455^{\mathrm{B}}$ \\
\hline PEG 30\% & $0.816 \pm 0.082^{\mathrm{b}}$ & $0.977 \pm 0.125^{\mathrm{b}}$ & $0.382 \pm 0.087^{\mathrm{ac}}$ & $0.725^{\mathrm{C}}$ \\
\hline Average & $0.580^{\mathrm{A}}$ & $0.649^{\mathrm{B}}$ & $0.317^{\mathrm{C}}$ & \\
\hline
\end{tabular}

Numbers are average from 3 replicates \pm SD. Means with same letters are not significantly different

Table 3: Total chlorophyll content of rice cultivars after three days PEG treatments.

\begin{tabular}{|c|c|c|c|c|}
\hline \multirow[b]{2}{*}{ Treatment } & \multicolumn{4}{|c|}{ Chlorophyll Content (mg/mL) } \\
\hline & 'Mansur' & 'Putih Cempaka' & 'IR64' & Average \\
\hline Control & $10.931 \pm 0.853^{\mathrm{a}}$ & $13.251 \pm 0.576^{\mathrm{a}}$ & $9.384 \pm 1.321^{\mathrm{a}}$ & $11.189^{\mathrm{A}}$ \\
\hline PEG 20\% & $8.355 \pm 1.258^{\mathrm{ab}}$ & $8.995 \pm 0.386^{\mathrm{a}}$ & $7.616 \pm 0.679^{\mathrm{ab}}$ & $8.322^{\mathrm{B}}$ \\
\hline PEG 30\% & $4.775 \pm 0.537^{\mathrm{b}}$ & $5.974 \pm 0.347^{b}$ & $6.465 \pm 0.636^{\mathrm{b}}$ & $5.671^{\mathrm{C}}$ \\
\hline Average & $8.020^{\mathrm{A}}$ & $9.41^{\mathrm{B}}$ & $7.821^{\mathrm{A}}$ & \\
\hline
\end{tabular}

Numbers are average from 3 replicates \pm SD. Means with same letters mean are not significantly different

\section{Discussion}

Drought stress inhibits cell division and cell growth, which lead to inhibition of plant growth and development (Sarvestani et al., 2008). Plant under drought stress develops physiological and genetic adaptation. The ratio of root to shoot increased in rice seedling that undergone drought stress. Bali local rice cultivars tested in this study had higher fresh weight root to shoot ratio as compared to 'IR64' both at PEG20\% and PEG 30\%. 'IR64' has the lowest root to shoot ratio, almost $1 / 3$ of that in 'Putih Cempaka'. 'IR64' has been known as drought sensitive rice cultivar (Prakash et al., 2016). The high root to shoot ratio is to increase water uptake (Xu et al., 2015). Root characteristics become important for selection of rice cultivars (Baloch et al., 2012). Thick and deep root is root characters that present in plant tolerant to drought stress.

Leaf colour in plant treated with PEG turned to be yellowish. Chlorophyll content decreased significantly under drought stress induced by PEG. Reduced chlorophyll content in drought stress rice seedling has been reported earlier (Dalal and Tripathy, 2012; Kadhimi et al., 2016). The decrease was caused by lack of chlorophyll biosynthetic intermediates, due to down-regulation of gene expression of enzymes for chlorophyll biosynthesis (Dalal and Tripathy, 2012). Another explanation for reduced chlorophyll content was chlorophyll degradation which leads to senescence (Chen et al., 2015).

In this study, under 30\% PEG, 'IR64' had the highest chlorophyll content $(6.465 \mathrm{mg} / \mathrm{ml})$ followed by 'Putih Cempaka' $(5.974 \mathrm{mg} / \mathrm{mL})$. It was demonstrated that high chlorophyll content is a desirable trait for screening drought tolerant due to low photosynthesis inhibition (Moaveni, 2011). Drought stress enhances the production of Reactive Oxygen Species (ROS) that cause stress oxidative in chloroplast and decrease chlorophyll content (de Carvalho, 2008). High ROS production functions as a signal for activation of a system for protection from oxidative damage (You and Chan, 2015).

The $D R E B$ gene used for this study was classified as the DREB1 transcription factor (Pharmawati and Kurniasih, 2016). In this study, there was an increase in gene expression of $D R E B$ las a response to drought stress. However, in 'IR64' the DREB1 expression only increased at $20 \%$ PEG but decreased at $30 \%$ PEG indicating low oxidative defense at high concentration of PEG. The decrease of expression may be related to the characteristics of 'IR64' as drought susceptible cultivar. The increase of DREB1 expression shows better tolerance to drought in several crop species including rice (Joshi et al., 2016). Studies have shown that transgenic over-expression of DREB1F improve tolerance to drought stress induced by PEG 6000 and airdrying in rice (Wang et al., 2008) and transgenic rice 
that over-expressed $D R E B 1 G$ and $D R E B 1 E$ have a better rate of survival under drought (Chen et al., 2008).

DNA sequence analysis of SOD gene used in this study revealed that the sequence had high similarity with SODCc1 (cytosolic copper/zinc】 superoxide dismutase) gene (Pharmawati and Kurniasih, 2016). The increase of SODCCl expression was detected in 'Mansur' and 'Putih Cempaka', while in 'IR64' this gene was not detected. In this experiment, the $S O D$ primer pair used was designed by Singh and Sadasivam (2003). The primer pair was reported to amplify a new isomer of SOD which does not present in droughtsensitive rice plant. Singh and Sadasivam (2003) shown that this isoform was absent in 'IR64'.

The induction of $S O D$ expression indicates its important role in the defense mechanism of the plant (Ashraf and Ali, 2008). It was reported that in the vegetative stage of rice, the expression of $\mathrm{Cu} / \mathrm{Zn}-\mathrm{SOD}$ increased under drought both in drought-sensitive and drought-tolerant cultivar, however, the dominant expression was found in drought tolerant cultivar (de Deus et al., 2015). The increase of SOD expression under drought has been reported in 'Situ Bagendit', a local rice cultivar from Indonesia (Refli et al., 2014).

Morpho-physiological, as well as genetic responses of rice cultivar 'Mansur', 'Putih Cempaka' and 'IR64' evaluated in this study, provide information for the future breeding program to develop cultivar tolerant to water deficit. Based on morpho-physiological data, among two local rice cultivars tested, 'Putih Cempaka' showed the highest fresh weight root to shoot ratio and higher chlorophyll content. The expression of DREB1 and $S O D$ in 'Putih Cempaka' increased at 30\% PEG treatment indicating the involvement of transcription factor to withstand drought stress as well as showing oxidative defense.

\section{Conclusion}

Drought stress increased fresh weight root to shoot ratio and reduced chlorophyll content in rice cultivars 'Mansur', 'Putih Cempaka' and 'IR64'. The expression of DREB1 and SOD increased in 'Mansur' and 'Putih Cempaka'. Further study in the field,need to be done to evaluate 'Mansur' and 'Putih Cempaka' production under drought stress. Furthermore, based on the root to shoot ratio as well as DREBI and SOD, 'Mansur' and 'Putih Cempaka' can be used as materials in rice breeding to develop drought-tolerant cultivars.

\section{Acknowledgement}

This research was funded by Ministry of Research Technology and Higher Education of Republic Indonesia through Fundamental Research Grant no. 486.126/UN14.2/PNL.01.03.00/2016

\section{Author Contributions}

Made Pharmawati: Designed the experiments, performed gene expression analyses and prepared manuscript.

Luh Putu Wrasiati: Performed morphophysiological analyses and prepared manuscript.

\section{References}

Aydin, S., I. Buyuk and E.S. Aras, 2014. Expression of SOD gene and evaluating its role in stress tolerance in $\mathrm{NaCl}$ and PEG stressed Lycopersicum esculentum. Turk. J. Bot., 38: 89-98. DOI: 10.3906/bot-1305-1

Arnon, D.I., 1949. Copper enzymes in isolated chloroplasts. Polyphenoloxidase in Beta vulgaris. Plant Physiol., 24: 1-15. DOI: 10.1104/pp.24.1.1

Ashraf, M. and Q. Ali, 2008. Relative membrane permeability and activities of some antioxidant enzymes as the key determinants of salt tolerance in canola (Brassica napus L.). Environ. Exp. Bot., 63: 266-273. DOI: /10.1016/j.envexpbot.2007.11.008

Baloch, M.J., J. Dunwell, A.A. Khakwani, M. Dennett and W.A. Jatoi et al., 2012. Assessment of wheat cultivars for drought tolerance via osmotic stress imposed at early seedling growth stages. J. Agric. Res., 50: 299-310.

Bartels, D. and D. Nelson, 1994. Approaches to improve stress tolerance using molecular genetics. Plant Cell Environ., 17: 1659-1667. DOI: $10.1111 / \mathrm{j} .1365-3040.1994 . t b 00157 . \mathrm{x}$

Budiwati, G.A.N., 2016. Aspek biologi dan hubungan kekerabatan padi local (Oryza sativa L.) di Desa Wongaya Gede, Kecamatan Penebel, Kabupaten Tabanan, Bali. Tesis. Program Pascasarjana, Universitas Udayana, Bali, Indonesia.

Chen, J.Q., X.P. Meng., Y. Zhang, M. Xia and X.P. Wang, 2008. Over-expression of OsDREB genes lead to enhanced drought tolerance in rice. Biotechnol. Lett., 30: 2191-2198.

DOI: $10.1007 / \mathrm{s} 10529-008-9811-5$

Chen, D., S. Wang, B. Xiong, B. Cao and X. Deng, 2015. Carbon/Nitrogen imbalance associated with drought-induced leaf senescence in Sorghum bicolor. PLoS, 10: e0137026-e0137026.

DOI: 10.1371/journal.pone.0137026

Dalal, V.K. and B.C. Tripathy, 2012. Modulation of chlorophyll biosynthesis by water stress in rice seedlings during chloroplast biogenesis. Plant Cell Environ., 35: 1685-1703.

DOI: $10.1111 /$ j.1365-3040.2012.02520.x 
de Carvalho, M.J.C., 2008. Drought stress and reactive oxygen species: Production, scavenging and signaling. Plant Signal. Behav., 3: 156-165. DOI: $10.4161 /$ psb.3.3.5536

de Deus, K.E., A.C. Lanna, F.R.M. Abreu, R.D.D. Silveira and W.J. Pereira et al., 2015. Molecular and biochemical characterization of Superoxide Dismutase (SOD) in upland rice under drought. Aus. J. Crop Sci., 9: 744-753.

Eghball, B. and J.W Maranville, 1993. Root development and nitrogen influx of corn genotypes grown under combined drought and nitrogen stresses. Agron. J., 85: 147-152.

DOI: 10.2134/agronj1993.00021962008500010027x

Farooq, M., M. Hussain, A. Wahid and K.H.M. Siddique, 2012. Drought Stress in Plant: An Overview. In: Plant Responses to Drought Stress, Aroca, R. (Ed.), Springer, Berlin, pp: 1-33.

Jadhao, K.R., K.C. Samal, S.K. Pradhan and G. Rout, 2014. Studies on molecular characterization of DREB gene in indica rice (Oryza sativa L.). Hered. Genet., 3: 133-133.

DOI: $10.4172 / 2161-1041.1000133$

Joshi, R., S.H. Wani, B. Singh, A. Bohra and Z.A.D. Dar et al., 2016. Transcription factors and plants response to drought stress: Current understanding and future directions. Frontier Plant Sci., 7: 1029-1029. DOI: 10.3389/fpls.2016.01029

Kadhimi, A.A., C.R.C.M. Zain, A.N. Alhasnawi, A. Isahak and M.F. Ashraf et al., 2016. Effect of irradiation and polyethylene glycol on drought tolerance of MR269 genotype rice (Oryza sativa L.). Asian J. Crop Sci., 8: 52-59. DOI: $10.3923 /$ ajcs.2016.52.59

Karim, M.R. and M.A. Rahman, 2015. Drought risk management for increased cereal production in Asian Least Developed Countries. Weather Clim. Extremes, 7: 24-35.

DOI: $10.1016 /$ j.wace. 2014.10 .004

Khush, G. and P. Virk, 2005. IR varieties and their impact. International Rice Research Institute, Los Banos, Philippines.

Lima, J.M., M. Nath, P. Dokku, K.V. Raman and K.P. Kulkarni et al., 2015. Physiological, anatomical and transcriptional alterations in a rice mutant leading to enhanced water stress tolerance. AoB Plants, 7: plv023-plv023. DOI: 10.1093/aobpla/plv023

Naylor, R.L, D.S. Battisti, D.J. Vimont, W.P. Falcon and M.B. Burke, 2007. Assessing risks of climate variability and climate change for Indonesian rice agriculture. Proc. Natl. Acad. Sci., 104: 7752-7757. DOI: $10.1073 /$ pnas.0701825104

Moaveni, P., 2011. Effect of water deficit stress on some physiological traits of wheat (Triticum aestivum). Agric. Sci. Res. J., 1: 64-68
Pardo, J.M., M.P. Reddy, S. Yang, A. Maggio and G.H. Huh et al., 1998. Stress signaling through $\mathrm{Ca}^{2+/}$ calmodulin-dependent protein phosphatase calcineurin mediates salt adaptation in plants. Proc. Natl. Acad. Sci. USA, 95: 9681-9686. DOI: $10.1073 /$ pnas.95.16.9681

Pharmawati, M. and E.M. Kurniasih, 2016. Characterization of partial DREB and SOD genes from three Bali local rice cultivars. AIP Conf. Procee., 1744: 020037-020037.

DOI: $10.1063 / 1.4953511$

Prakash, C., S.V.A. Mithra, P.K. Singh, T. Mohapatra and N.K. Singh, 2016. Unraveling the molecular basis of oxidative stress management in a drought tolerant rice genotype Nagina 22. BMC Genom., 17: 774-774. DOI: 10.1186/s12864-016-3131-2

Refli, R., S. Muljopawiro, K. Dewi and D. Rachmawati, 2014. Expression analysis of antioxidant genes in response to drought stress in the flag leaf of two Indonesian rice cultivars. Indonesian J. Biotechnol., 19: 43-55. DOI: 10.22146/ijbiotech.8633

Romo, S.E., B. Labrador and Dopico, 2001. Water stress-regulated gene expression in Cicer arietinum seedlings and plants. Plant Physiol. Biochem., 39: 1017-1026. DOI: 10.1016/S0981-9428(01)01318-3

Roy, R., P.B. Mazumer and G.D. Sharma, 2009. Proline, catalase and root traits as indices of drought resistance in bold grained rice (Oryza sativa) genotypes. Afr. J. Biotechnol., 8: 6521-6528.

Sambrook, J. and R.W. Russell, 2001. Molecular Cloning: A Laboratory Manual. 3rd Edn., Cold Spring Harbor Laboratory Press, Cold Spring Harbor, N.Y., ISBN-10: 0879695773, pp: 2344.

Sarvestani, Z.T., H. Pirdashti, S.A.M. Sanavy and H. Balouchi, 2008. Study of water stress effects in different growth stages on yield and yield components of different rice (Oryza sativa L.) cultivars. Pak. J. Biol. Sci., 11: 1303-1309.

DOI: $10.3923 /$ pjbs.2008.1303.1309

Singh, K.N. and S. Sadasivam, 2003. Identifying a Novel Superoxide Dismutase Isoform: A Biological Marker for Evaluating Drought-Tolerant Varieties of Rice. In: Advance in Rice Genetics, Khush, G.S., D.S. Brar and B. Hardy (Eds.), IRRI, Manila, Philippine, ISBN-10: 9712201996, pp: 449-451.

Wang, Q., Y. Guan, Y. Wu, H. Chen and F. Chen et al., 2008. Overexpression of a rice OsDREB1F gene increases salt, drought and low temperature tolerance in both Arabidopsis and rice. Plant Mol. Biol., 67: 589-602.

DOI: $10.1007 / \mathrm{s} 11103-008-9340-6$

Wang, H.H., M.E. Naredo, J.L. Wu, B.J. Till and E.A. Greene et al., 2004. EcoTILLING Candidate Genes for Drought Tolerance in Rice. In: Resilience Crops for Water Limited Environment, Poland, D. (Ed.), Cuernavaca, Mexico, CIMMYT, ISBN-10: 9706481249, pp: 75-76. 
Xu, W., K. Cui, A. Xu, L. Nie and J. Huang et al., 2015. Drought stress condition increases root to shoot ratio via alteration of carbohydrate partitioning and enzymatic activity in rice seedling. Acta Physiol. Plan., 37: 9. DOI: 10.1007/s11738-014-1760-0

You, J. and Z. Chan, 2015. ROS regulation during abiotic stress responses in crop plants. Frontiers Plant Sci., 6: 1092-1092.

DOI: $10.3389 /$ fpls.2015.01092
Yu, S.W., Y. Liu and L.J. Luo, 2007. Analyses of relative gene expression using different realtime quantitative PCR. Acta Agron. Sinica, 33: 1214-1218. 